\title{
PROLONGED ANTIOESTROGENIC ACTIVITY OF ICI 46,474 IN THE OVARIECTOMIZED MOUSE
}

\author{
V. G. JORDAN* \\ Worcester Foundation for Experimental Biology, \\ Shrewsbury, Massachusetts 01545, U.S.A.
}

(Received 8th Fune 1974)

\begin{abstract}
Summary. Subcutaneous administration of ICI $46,474(3 \mathrm{mg})$ to ovariectomized mice was found to produce vaginal refractoriness to subcutaneously administered oestradiol for up to 6 weeks.

Tritiated oestradiol-17 $\beta$ accumulated in the uterus and vagina of the ovariectomized mouse, with maximum accumulation at 3 to $4 \mathrm{hr}$. This property of the target tissues was used to investigate the binding of tritiated oestradiol after the administration of $3 \mathrm{mg}$ ICI 46,474 to ovariectomized mice. Radioactivity in the vagina was found to be comparable to control values 6 weeks after IGI 46,474 administration; uterine levels of radioactivity returned to control values by 10 weeks.

Administration of ICI 46,474 had an oestrogenic effect upon the mouse uterus whereas the vagina appeared to be initially stimulated and was then unable to respond to or to bind oestradiol.
\end{abstract}

\section{INTRODUCTION}

It has been reported that ICI 46,474 , the trans-isomer of 1 -(p- $\beta$-dimethyl aminoethoxyphenyl)-1,2-diphenylbut-1-ene, is a potent antioestrogen in the rat (Harper \& Walpole, 1966) and is effective in preventing implantation by inhibiting the uterine response to the oestrogen surge if administered during the first 4 days after mating (Harper \& Walpole, 1967a, b). In the mouse, oestrogenic activity only was demonstrated (Harper \& Walpole, 1966), although ICI 46,474 was found to be a potent antifertility agent (Collins, Hobbs \& Emmens, 1971). Further work in the mouse showed that ICI 46,474 was inactive as an antiuterotrophic agent (Terenius, 1970) but exhibited oestrogenic activity which closely paralleled that of oestradiol-17 $\beta$ (Terenius, 1971). By contrast, Emmens (1971) demonstrated that, after the subcutaneous administration of large doses of ICI 46,474 to ovariectomized mice, the vaginal epithelium was unable to respond for many weeks to periodic oestradiol administration.

In the present investigation, the ability of the uterus and vagina to accumulate radio-labelled oestradiol in vivo at various times after the administration of 'antioestrogenic' doses of ICI 46,474 was determined, and the findings were compared with the ability of the vagina to respond to oestrogen.

* Present address: Department of Pharmacology, School of Medicine, Leeds LS2 9NL. 


\section{MATERIALS AND METHODS}

Mature female mice (20 to $25 \mathrm{~g}$; Charles River CD strain) were ovariectomized under ether anaesthesia and were primed 2 weeks later with $1 \mu \mathrm{g}$ oestradiol- $17 \beta$. For all experiments, the mice were used 2 weeks after priming. All substances were dissolved in $0.05 \mathrm{ml}$ peanut oil for injection.

\section{Allen-Doisy test}

Solutions were prepared in peanut oil from fresh alcoholic stock solutions. The method of Emmens (1969) was used with minor modifications. The oestradiol-17 $\beta$ (Sigma Chemical Co.) or ICI 46,474 (ICI Pharmaceuticals U.K.) was administered subcutaneously at different injection sites on the mornings of 2 consecutive days. On the evening of the 3rd day and on the morning of the 4th day, smears were taken from the dorsal surface of the vagina with a moistened platinum loop and examined without staining under a low power microscope. Smears were recorded as positive if cornified cells only were present and as negative if leucocytes were present. The results were expressed as the percentage response of the total number of smears per group and as the percentage of animals with positive smears.

The method of Emmens (1971) was used to determine the long-term antioestrogenic effect of ICI 46,474. The treated and control animals were given a total dose of $0.1 \mu \mathrm{g}$ oestradiol-17 $\beta$ subcutaneously in Allen-Doisy tests at 2-week intervals. Smears were taken as described above.

\section{Uptake of radioactivity}

The $\left[6,7-{ }^{3} \mathrm{H}\right]$ oestradiol- $17 \beta(48 \mathrm{Ci} / \mathrm{mmol})$ was obtained from the New England Nuclear Corporation with $97 \%$ purity and was used without further purification. The required amount was evaporated to dryness under nitrogen (with gentle warming), dissolved in a few drops of absolute ethanol (U.S.P. reagent quality) and the calculated volume of peanut oil was added. The alcohol was then evaporated under nitrogen.

Primed ovariectomized mice were killed by cervical dislocation $\frac{1}{2}, 1,2,3$ and $4 \mathrm{hr}$ after subcutaneous administration of $0.019 \mu \mathrm{g}$ tritiated oestradiol-17 $\beta$ (3.3 $\mu \mathrm{Ci})$. The uterus, vagina, apex of the heart and a sample of liver were dissected out, blotted, weighed, wrapped in 5-cm squares of paper tissue and combusted to tritiated water in a Packard tissue oxidizer. Counting was performed in a mixture of modified Bray's solution (100 $\mathrm{g}$ naphthalene, $7 \mathrm{~g}$ butylphenyl-5-(4biphenyl)-1,3,4-oxadizole: Packard), $730 \mathrm{ml}$ dioxane, $135 \mathrm{ml}$ toluene, and 35 $\mathrm{ml}$ ethanol) in a Packard liquid scintillation spectrometer. The counting efficiency was 38 to $40 \%$.

\section{Long-term effects of ICI 46,474}

The ICI $46,474(1.5 \mathrm{mg})$ was administered subcutaneously to primed ovariectomized mice on 2 consecutive days. Control mice received peanut oil.

After obtaining vaginal smears, ten treated and ten control mice were dosed subcutaneously with $0.019 \mu \mathrm{g}\left[6,7-{ }^{3} \mathrm{H}\right]$ oestradiol- $17 \beta(3.3 \mu \mathrm{Ci})$ at 1 week, 2 weeks and then at 14-day intervals up to 10 weeks after administration of the 
ICI 46,474 . The animals were killed $3 \mathrm{hr}$ after the oestradiol injection and the uterus, vagina, liver and heart tissues were dissected out, blotted, weighed and dried for $24 \mathrm{hr}$ in an oven at $60^{\circ} \mathrm{C}$. The tissues were then reweighed and processed as above. The results were expressed as ct $/ \mathrm{min} / \mathrm{mg}$ wet weight or $\mathrm{ct} / \mathrm{min} /$ mg dry weight.

\section{RESULTS}

Allen-Doisy tests

The results of these tests (Table 1) with the simultaneous administration of ICI 46,474 and oestradiol-17 $\beta$ demonstrated that ICI 46,474 at 1- and 3-mg

Table 1. The effect of ICI 46,474 on the response of ovariectomized mice to oestradiol-17 $\beta$

\begin{tabular}{|c|c|c|c|c|c|c|}
\hline \multirow{2}{*}{$\begin{array}{l}\text { Total dose of } \\
\text { ICI 46,474* } \\
\quad(m g)\end{array}$} & \multirow{2}{*}{$\begin{array}{c}\text { Total dose of } \\
\text { oestradiol-17 } \beta^{*} \\
(\mu g)\end{array}$} & \multirow{2}{*}{$\begin{array}{l}\% \text { Positive } \\
\text { smears } \dagger\end{array}$} & \multirow{2}{*}{$\begin{array}{l}\% \text { Mice } \\
\text { reacting }\end{array}$} & \multicolumn{3}{|c|}{$\begin{array}{l}\% \text { Mice reacting to a total dose } \\
\text { of } 0.1 \mu \mathrm{g} \text { oestradiol- } 17 \beta^{*} \text { at: }\end{array}$} \\
\hline & & & & 2 weeks & 4 weeks & 6 weeks \\
\hline $\begin{array}{l}\overline{1.0} \\
3.0 \\
1.0 \\
3.0\end{array}$ & $\begin{array}{c}0.06 \\
\overline{-} \\
0.06 \\
0.06\end{array}$ & $\begin{array}{l}80 \\
80 \\
80 \\
95 \\
80\end{array}$ & $\begin{array}{r}100 \\
100 \\
90 \\
100 \\
100\end{array}$ & $\begin{array}{r}100 \\
60 \\
30 \\
80 \\
0\end{array}$ & $\begin{array}{r}100 \\
100 \\
50 \\
90 \\
20\end{array}$ & $\begin{array}{r}100 \\
100 \\
90 \\
100 \\
80\end{array}$ \\
\hline
\end{tabular}

* Sub-doses given subcutaneously on 2 consecutive days.

$\uparrow$ Ten mice/group.

Table 2. The uptake and retention of radioactivity by the uterus, vagina, liver and heart after administration of $\left[6,7^{3} \mathrm{H}\right]$ oestradiol-17 $\beta$ to ovariectomized mice

\begin{tabular}{c|r|r|r|r}
\hline \multirow{2}{*}{$\begin{array}{c}\text { Time after } \\
{\left[6,7-{ }^{3} \text { Hoestradiol-17 } \beta^{*}\right.}\end{array}$} & \multicolumn{4}{|c}{ Tissue radioactivity $(\mathrm{ct} / \mathrm{min} / \mathrm{mg}$ wet wt $)$} \\
\cline { 2 - 5 }$(\mathrm{hr})$ & \multicolumn{1}{|c|}{ Uterus } & \multicolumn{1}{|c}{ Vagina } & \multicolumn{1}{c}{ Liver } & \multicolumn{1}{c}{ Heart } \\
\hline 0.5 & $68 \pm 10$ & $40 \pm 5$ & $106 \pm 15$ & $16 \pm 2$ \\
$1 \cdot 0$ & $100 \pm 12$ & $71 \pm 9$ & $83 \pm 7$ & $11 \pm 1$ \\
$2 \cdot 0$ & $292 \pm 25$ & $109 \pm 13$ & $90 \pm 11$ & $10 \pm 1$ \\
3.0 & $281 \pm 21$ & $160 \pm 20$ & $62 \pm 10$ & $9 \pm 1$ \\
$4 \cdot 0$ & $295 \pm 10$ & $176 \pm 12$ & $51 \pm 4$ & $7 \pm 1$ \\
\hline
\end{tabular}

Values are means \pm S.E.M. Five mice/group.

* Given subcutaneously as $0.019 \mu \mathrm{g}(3.3 \mu \mathrm{Ci})$.

doses was entirely oestrogenic and was unable to antagonize the vaginal cornification produced by a total dose of $0.06 \mu \mathrm{g}$ oestradiol- $17 \beta$. The administration of $0 \cdot 1 \mu \mathrm{g}$ oestradiol-17 $\beta$ at 14 -day intervals produced $100 \%$ vaginal cornification in the control mice whereas the mice were unable to respond to the administered oestradiol 2 weeks after treatment with $3 \mathrm{mg}$ ICI 46,474. The proportion of animals responding gradually increased over the 6-week testing period. This effect was only partly produced when $1 \mathrm{mg}$ ICI 46,474 was given.

\section{Uptake of radioactivity}

The time course of the retention of radioactivity in the uterus, vagina, liver 


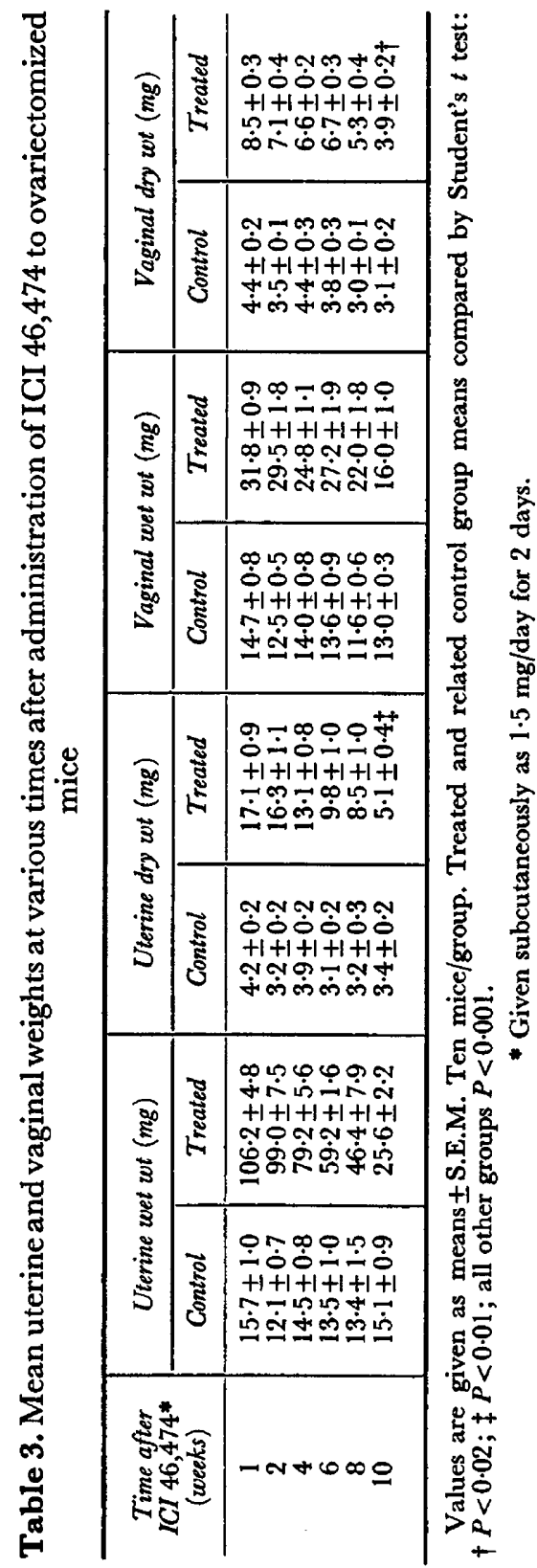




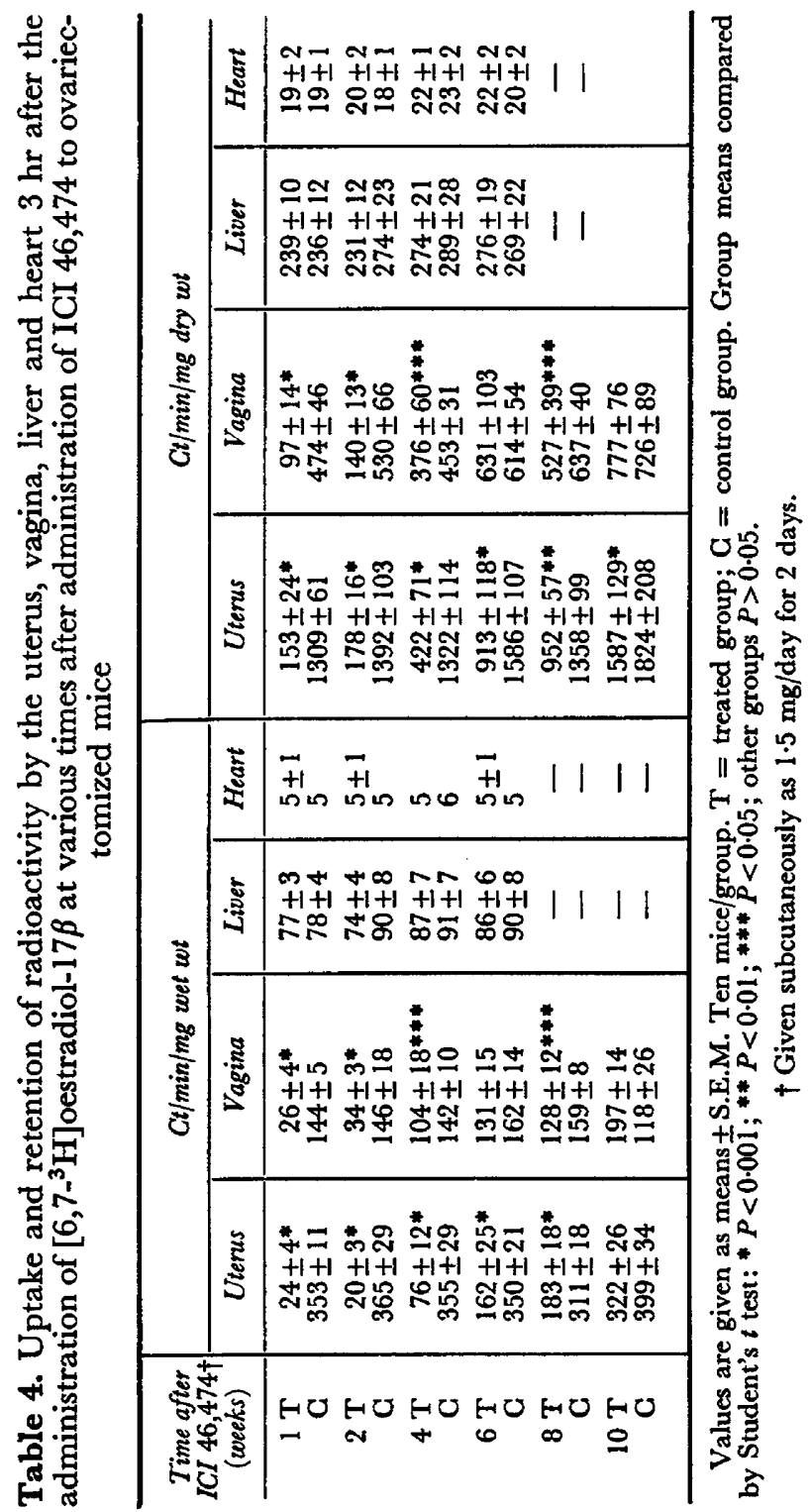


and heart was determined using primed ovariectomized mice (Table 2). Levels of radioactivity in the liver and heart (non-target tissues) were highest at $\frac{1}{2} \mathrm{hr}$ but by $4 \mathrm{hr}$ this level was reduced by $50 \%$. By contrast, the levels of radioactivity in the uterus and vagina steadily increased to a plateau at 2 to $4 \mathrm{hr}$ for the uterus and at 3 to $4 \mathrm{hr}$ for the vagina. At all times, uterine levels were greater than those in the vagina and maximal uterine levels were three times the maximum level reached in the liver tissue.

Of the five time periods studied, $3 \mathrm{hr}$ after the administration of tritiated oestradiol was selected as a suitable time period to demonstrate uptake and retention of radioactivity by target tissues.

\section{Long-term effects of ICI 46,474}

At 1 week after administration of ICI $46,474,60 \%$ of the vaginal smears were positive, but thereafter all were negative. The uterine weights of the animals at autopsy decreased progressively over the 10 weeks of the experiment. Between 4 and 8 weeks, large fluid-filled glands were observed in the uteri.

As the uterine and vaginal weights decreased, there was increased ability to retain radioactivity (Tables 3 and 4), but although the vaginal levels of radioactivity returned to control values by 6 weeks, the uterine levels did not return to control levels for 10 weeks. No differences were found between the treated and control animals in the levels of radioactivity found either in the liver or in the heart (Table 4).

\section{DISCUSSION}

The results of the Allen-Doisy tests (Table 1) after the subcutaneous administration of ICI 46,474 closely parallel the results reported by Emmens (1971). Harper \& Walpole $(1966,1967$ a) have previously shown that ICI 46,474, like its cis-isomer ICI 47,699, is only oestrogenic in conventional short-term AllenDoisy tests, and Terenius (1971) has shown that both isomers are uterotrophic in conventional immature mouse uterine weight tests.

The effects of large subcutaneous doses of ICI 46,474 on the uterus and vagina appear to be different. The uterus is initially stimulated and slowly returns towards control uterine weights over a 10-week period (Table 3 ), while the vagina is initially stimulated and then reverts to a dioestrous state within 2 weeks but remains refractory to oestradiol (Table 1). A similar effect has been reported (Emmens, 1971; Emmens \& Carr, 1973) for two structurally related compounds, H774 (1-(p- $\beta$-diethylaminoethoxyphenyl)-1,2-di(pmethoxyphenyl)-but-1-ene citrate) and H1076 (1-(p- $\beta$-diethylamino ethoxyphenyl)-1,2-di(p-methoxyphenyl)-3-methyl-but-1-ene-hydrochloride).

Jensen \& Jacobson (1962) demonstrated the selective accumulation of radiolabelled oestradiol in rat target tissues, and Stone (1963) reported a similar pattern of selective uptake by target tissues in the ovariectomized mouse. Both studies demonstrated that oestradiol was not metabolized before binding to the target tissues. The present results shown in Table 2 illustrate the selective accumulation of radioactivity by oestrogen-sensitive tissues of the mouse.

A non-steroidal antioestrogen, MER 25, first described by Lerner, Holthaus \& Thompson (1958), has been shown to inhibit the uptake of tritiated oestradiol 
by mouse uterus and vagina in vivo (Stone, 1964). Terenius (1971) has shown that ICI 46,474 is capable of inhibiting the uptake of tritiated oestradiol by the mouse uterus in vitro, and the results of the present study (Table 4) show that this substance can inhibit oestradiol uptake in the mouse uterus and vagina in vivo. The uptake of oestradiol in the uterus increases as uterine wet weight and dry weight decrease.

Skidmore, Walpole \& Woodburn (1972) have demonstrated ultrastructurally that ICI 46,474 binds to a cytoplasmic macromolecule derived from rat, rabbit or mouse uteri, thereby inhibiting the binding of oestradiol. Using a sucrose density gradient technique, unpublished results from this laboratory have shown that ICI 46,474 and H774 inhibit the binding of oestradiol to $8 \mathrm{~S}$ oestrogen-binding macromolecules derived from mouse uterus and vagina.

The calculated $t_{\frac{1}{2}}$ for an oral dose of ICI $46,474(40 \mathrm{mg} / \mathrm{kg})$ has been reported to be 18 days (Fromson, Pearson \& Branah, 1973). It is possible, therefore, that circulating levels of ICI 46,474 could persist for up to 10 weeks, producing uterine stimulation and receptor blockade. The effect upon the vagina is apparently more transient, with an initial presentation of oestrogenic effects followed by a dioestrous state lasting for up to 6 weeks, when the antioestrogenic effects of ICI 46,474 disappear.

Emmens (1971) has shown that oral administration of $\mathrm{H} 774$ or $\mathrm{H} 1076$ to ovariectomized mice does not produce long-term refractory states, but that subcutaneous administration is effective. The subcutaneous administration of large doses of ICI 46,474 may therefore produce a slow release depôt. This would explain the increasing ability of target tissues to accumulate radioactivity with increasing time. The vaginal refractoriness to oestrogen is not accounted for by this explanation.

Clark, Anderson \& Peck (1973) have reported that, after a single dose of 100 $\mu \mathrm{g}$ of the antioestrogen, nafoxidine hydrochloride (U-11,100A), the oestrogen receptors were retained by the uterine cell nuclei for up to 19 days in rats but that the cytoplasmic receptor was not replenished. They suggested that the antioestrogenic activity of $\mathrm{U}-11,100 \mathrm{~A}$ was associated with its ability to inhibit cytoplasmic receptor replenishment.

It is possible that ICI 46,474 could act by a similar mechanism to leave the vaginal cells unstimulated and unable to bind oestradiol. Work is now in progress to investigate the ability of ICI 46,474 to regulate oestrogen receptor synthesis and to determine the effect of the refractory state produced by large doses of ICI 46,474 on the induction and growth of rat mammary carcinoma induced by administration of dimethylbenzanthracene.

\section{ACKNOWLEDGMENTS}

Thanks are due to Dr A. L. Walpole (ICI Pharmaceuticals) for the gift of ICI 46,474. The study was supported by AID contract Aid/CSD-2837.

\section{REFERENCES}

Clark, J. H., Anderson, J. N. \& Peck, E. J. (1973) Estrogen, receptor, antiestrogen complex: atypical binding by uterine nuclei and effects on uterine growth. Steroids, 22, 707-718. 
Collins, D. J., Hoввs, J. J. \& Emmens, C. W. (1971) Antiestrogenic and antifertility compounds. IV. 1,1,2-triarylalkan-1-ols and 1,1,2-trioxylalk-1-ens containing basic ether groups. F. med. Chem. 14, 952-957.

Emmens, G. W. (1969) Estrogens. In Methods in Hormone Research, Vol. 2A, p. 61. Ed. R. I. Dorfman. Academic Press, New York.

Emmens, C. W. (1971) Compounds exhibiting prolonged antioestrogenic and antifertility activity in mice and rats. F. Reprod. Fert. 26, 175-182.

Emmens, C. W. \& CARR, W. L. (1973) Further studies of compounds exhibiting prolonged antioestrogenic and antifertility activity in the mouse. 7. Reprod. Fert. 34, 29-40.

Fromson, J. M., Pearson, S. \& Branah, S. E. (1973) The metabolism of tamoxifen (I.C.I. 46,474). Part 1 : In laboratory animals. Xenobiotica, 3, 393.

Harper, M. J. K. \& Wal.pole, A. L. (1966) Contrasting endocrine activities of $c$ is and trans isomers in a series of substituted triphenylethylenes. Nature, Lond. 212, 87.

HARPER, M.J. K. \& WALPOLE, A. L. (1967a) A new derivative of triphenylethylene: effect on implantation and mode of action in rats. F. Reprod. Fert. 13, 101-119.

HARPER, M. J. K. \& WalPole, A. L. (1967b) Mode of action of ICI 46,474 in preventing implantation in rats. F. Endocr. 37, 83-92.

Jensen, E. V. \& Jacobson, H. I. (1962) Basic guides to the mechanism of estrogen action. Recent Prog. Horm. Res. 18, 388-408.

Lerner, L. J., Holthaus, J. F. \& Thompson, C. R. (1958) A nonsteroidal estrogen antagonist; 1-(p-2diethylamine ethoxyphenyl)-1-phenyl-2-p-methoxyphenyl ethanol. Endocrinology, 63, 295-318.

SkIDMORE, J., WALPOLE, A. L. \& WoodBuRN, J. (1972) Effect of some triphenylethylenes on oestradiol binding in vitro on macromolecules from uterus and anterior pituitary. F. Endocr. 52, 289-298.

Stone, G. M. (1963) The uptake of tritiated oestrogens by various organs of the ovariectomized mouse following subcutaneous administration. F. Endocr. 27, 281-288.

Stone, G. M. (1964) The effect of oestrogen antagonists on the uptake of tritiated oestradiol by the uterus and vagina of the ovariectomized mouse. F. Endocr. 29, 127-136.

Terenrus, L. (1970) Two modes of interaction between oestrogen and antioestrogen. Acta endocr., Coperh. 64, 47-58.

TERENIUs, L. (1971) Structure-activity relationships of anti-oestrogens with regard to interaction with $17 \beta$-oestradiol in the mouse uterus and vagina. Acta endocr., Copenh. 66, 431-447. 